\title{
A QUESTÃO DO NEGRO BRASILEIRO REVISTADA
}

SILVA, Jakceli Costa da - jakcelicosta@gmail.com, 8o período, ADM / UEMG - noturno PESSOA, Marcelo - Docente UEMG e Orientador - https://orcid.org/0000-0002-9193-4604

RESUMO: A análise da inserção do negro no mercado de trabalho é bastante complexa e se faz mais evidente pelo vislumbre histórico de fatos migratórios associados ao negro escravizado e trazido às colônias europeias a partir do Século XVI. Justifica nosso estudo, o dado de que o desejo das equidades raciais no Brasil ao mesmo tempo em que é causa negra, influencia diretamente toda a população econômica ativa (AYERBE, 2002). Por objetivo geral, esta pesquisa investiga a ideia de que a diplomacia brasileira pode ter tido papel determinante nos fatores econômicos relacionados ao negro brasileiro escravizado. Especificamente, espera-se compreender como os diplomatas podem ter atuado na transmutação das assimetrias históricas, particularmente às ligadas à libertação do negro brasileiro. Como resultado parcial, pode-se notar que o nosso país, desde o seu descobrimento e exploração colonial, passou por períodos de transformações, cujas potências socioculturais ainda não foram suficientes para promover a quebra da hegemonia branca em todos os segmentos sociais.

PALAVRAS-CHAVE: Inclusão social, negritude, sociedade

ABSTRACT: The analysis of the insertion of blacks in the labor market is quite complex and is made more evident by the historical glimpse of migratory facts associated with black enslaved and brought to European colonies from the 16th century. Our study justifies the fact that the desire for racial equity in Brazil while being a black cause directly influences the entire active economic population (AYERBE, 2002). Overall, this research investigates the idea that Brazilian diplomacy may have played a determining role in the economic factors related to the enslaved Brazilian black. Specifically, we hope to understand how diplomats may have acted in the transmutation of historical asymmetries, particularly those linked to the liberation of the Brazilian Black. As a partial result, it can be noted that our country, since its discovery and colonial exploitation, has undergone periods of transformation, whose sociocultural powers have not yet been sufficient to promote the breakdown of white hegemony in all social segments.

KEYWORDS: Social Inclusion, blackness, society

\section{REFERÊNCIAS}

AYERBE, Luis Fernando. Estados Unidos e América Latina - a construção da hegemonia. São Paulo: UNESP, 2002. 